This paper deals with and highlights:

- regulations on advertising that apply to dental practice websites

- that existing websites may need updating to comply with Electronic Commerce Regulations

(2002)

- who is ultimately responsible for what appears in a website

- what dental practice websites need to do to comply with the regulations.

\title{
Does your practice website need updating?
}

\author{
L. D. Addy ${ }^{1}$, J. Uberoi, ${ }^{2}$ R. K. Dubal ${ }^{3}$ and R. McAndrew ${ }^{4}$
}

The internet is becoming a more and more powerful tool and many dental practitioners use it to advertise their dental service; some dental practices even offer on-line appointment booking! It is not unreasonable to surmise that use of the internet is likely to become increasingly common practice by dentists in the future. This is not surprising as the World Wide Web (WWW) provides an opportunity for dentists to advertise themselves and their practices to a wide audience in a relatively economical manner.

All forms of advertising in the UK are governed. Dentistry is no different. It is governed by regulations set by the General Dental Council (GDC). These can be found in the Maintaining Standards document ${ }^{1}$ or on the GDC website (www.gdc-uk.org). The regulations are set out to protect the public, and the GDC takes a serious view of any advertising or publicity material which is liable to mislead patients about the availability of treatment or the nature of the services provided.

Another set of regulations also exists, and it is the opinion of the authors that not many dentists are aware of them. These regulations came from the Electronic Commerce (EC Directive) Regulations 2002. They were highlighted in an article in the May/June 2002 edition of the $B D A$ News. This information was duplicated on the BDA website but has now been archived.

These European Union (EU) regulations mean that changes may be required to update existing dental practice websites in order for them to comply with these. New web sites will need to include the following: - the name and address of the practice(s)

- any e mail address(es), telephone or fax number(s)

\footnotetext{
${ }^{1-3}$ Adult Dental Health, University Dental Hospital, Cardiff; ${ }^{4}{ }^{*}$ House Officer, University Dental Hospital, Heath Park, Cardiff, CF14 4XY

Correspondence to: Dr Robert McAndrew

Email:mcandrew@cardiff.ac.uk

\section{Refereed Paper}

Received 20.08.03; Accepted 22.06.04

doi: 10.1038/sj.bdj.4812115
}

๑ British Dental Journal 2002; 198: 259-260
- the name of each dentist at the practice

- the professional qualifications and the country of qualification of each dentist at the practice

- registration information, including the dentists' registration number, the address and contact details of the General Dental Council (GDC), with a link to its website at www.gdc-uk.org

- a reference that the dentist adheres to the rules governing the profession (that is, guidance from the GDC, Maintaining Standards).

Information on acceptance of patients on the NHS is recommended. Other rules are:

- there must be no comparison in the description of care given at the practice, and at others, or of skills or qualifications of dentists at the practice and at other practices

- all changes in practice circumstances must be reflected in the website within one month of the change taking place (for example, changes in dentists working at the practice)

- sites must make it clear when the page was last updated.

Other aspects which may be included on the website include hours of opening, emergency care and range of care provided. A link to a professional association's website (eg the BDA) is also permitted. Links to other websites must be relevant and these websites should also reflect the principles of this code.

It was felt by the authors that not all dental practices would conform to the
European regulations. A survey of 101 dental practices advertising on the WWW confirmed this. We identified dental practices with websites from four web sources: www.yell.com, www.practicesearch.com, www.healthcentre.org.uk/hc/pages/ dentalsites and www.dentalguide.co.uk. Practices were chosen from the major cites and towns of England. Practices that were affiliated to corporate bodies were excluded as they were only advertising the corporate image rather than specific practices and their services.

Our results - shown in Table 1 showed that no dental practices were compliant with these EU regulations on web advertising. Fourteen per cent did not have their name on the web site which is also a requirement of advertising set by the Maintaining Standards document. Another regulation set out by the Maintaining Standards document is that no publicity or advertising material should indicate that a dentist has specialist expertise unless the dentist is the holder of a specialist title and the name is entered in a specialist list. Yet, in our small survey we found two (12\%) of the 17 practices with dentists with a claim to be specialists were not on the specialist list. It was also noted that a small number of practices were advertising in such a way that it could be open to misinterpretation by the general public. Statements including 'special services' and 'special care' for example, in the context of describing a practice may be misinterpreted by patients. It is the opinion of the authors that there should be some guidelines on the wording of such statements, making it 
very clear to the public if the dentist has an interest or is a registered specialist.

Another thing that was apparent from our survey was that many websites followed a similar pattern and were probably produced by web designers. Although we feel that dental practice web designers should also be aware of these regulations, it is important for dentists to remember that the responsibility for all publicity and advertising in relation to a practice rests with the dentist as stated in Maintaining Standards document.

It is our opinion that these EU guidelines have some crossover with the regulations on advertising set by Maintaining Standards document, but are set out as a defined checklist with great clarity. These very simple to follow regulations will allow dentists to provide a website that is honest and transparent to the general public so they can make an informed decision about whether to use your services. We feel that the GDC needs to advertise these regulations on their website or in their quarterly Gazette so that more dentists are aware of them. We also think that Maintaining Standards document should be updated to include internet advertising.

Below is a summary of what information should be found on a dental practice web site that can be used as a check list by practitioners.

1. Name, address and telephone numbers of the practice.

2.Email and fax number.

3. Name(s) of dentist(s) at the practice.

4. Qualifications and country of qualifications.

\begin{tabular}{|c|c|c|c|c|c|}
\hline \multicolumn{6}{|l|}{ Website evaluation } \\
\hline Question & YES & $\%$ & NO & $\%$ & Total \\
\hline Is the dentist's name on the web site? & 87 & 86 & 14 & 14 & 101 \\
\hline $\begin{array}{l}\text { Is the practice: } \\
\text { Address } \\
\text { Email } \\
\text { Tel No } \\
\text { on the web site? }\end{array}$ & $\begin{array}{l}90 \\
73 \\
90\end{array}$ & $\begin{array}{l}89 \\
72 \\
89\end{array}$ & $\begin{array}{l}11 \\
28 \\
11\end{array}$ & $\begin{array}{l}11 \\
28 \\
11\end{array}$ & $\begin{array}{l}101 \\
101 \\
101\end{array}$ \\
\hline $\begin{array}{l}\text { Does the dentist's qualification(s) appear } \\
\text { on the web site? }\end{array}$ & 70 & 69 & 31 & 31 & 101 \\
\hline $\begin{array}{l}\text { Does the dentist's country of qualification } \\
\text { appear on the web site? }\end{array}$ & 65 & 64 & 36 & 36 & 101 \\
\hline $\begin{array}{l}\text { Does the dentist's registration number } \\
\text { appear on the web-site? }\end{array}$ & 7 & 7 & 94 & 93 & 101 \\
\hline Is there a link to the GDC web site? & 17 & 17 & 84 & 83 & 101 \\
\hline $\begin{array}{l}\text { Is there a reference to the fact that the } \\
\text { dentist adheres to the rules governing } \\
\text { the profession? }\end{array}$ & 20 & 20 & 81 & 80 & 101 \\
\hline $\begin{array}{l}\text { Does the web site make claim to the fact } \\
\text { that the practitioner is a specialist in a } \\
\text { particular field of dentistry? }\end{array}$ & 17 & & 84 & & 101 \\
\hline $\begin{array}{l}\text { Is the above point substantiated? } \\
\text { (appearance on specialist list) }\end{array}$ & 15 & 88 & 2 & 12 & 101 \\
\hline $\begin{array}{l}\text { Does the web site indicate a dentist has a } \\
\text { particular dental interest? }\end{array}$ & 46 & 45.5 & 55 & 54.5 & 101 \\
\hline $\begin{array}{l}\text { Does the web site make reference to the } \\
\text { description of care given at the practice? }\end{array}$ & 79 & 78 & 22 & 22 & 101 \\
\hline $\begin{array}{l}\text { Does the web site indicate the last time } \\
\text { it was updated? }\end{array}$ & 11 & 11 & 90 & 89 & 101 \\
\hline Are the opening hours stated on the web site? & 79 & 78 & 22 & 22 & 101 \\
\hline $\begin{array}{l}\text { Does the web site make reference to the } \\
\text { type of practice? E.g. NHS, Private, Mixed }\end{array}$ & 65 & 64 & 36 & 36 & 101 \\
\hline $\begin{array}{l}\text { Does the web site have other dental links } \\
\text { other than the GDC one? }\end{array}$ & 45 & 44.5 & 56 & 55.5 & 101 \\
\hline
\end{tabular}

5. GDC number with link to GDC.

6. Date of last update.

Finally, remember, practitioners should only claim to be specialists if their name is on one of the GDC specialist lists.
1. General Dental Council. Maintaining standards: Guidance to dentists on professional and personal conduct. London, November 2001 